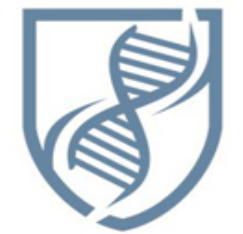

Journal of Bioscience and Applied Research

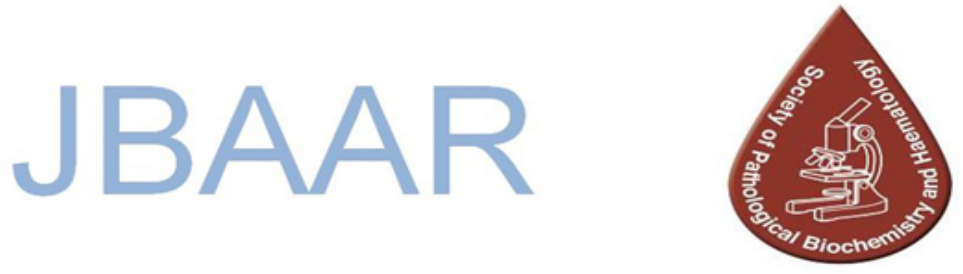

WWW.JBAAR.ORG

\title{
Effects of propolis on histopathological and immunohistochemical alterations in testes of thyroidectomized rat
}

\author{
Ezar Hafez \\ Zoology Department, Faculty of Science, Tanta University, Tanta 31527, Egypt \\ (Corresponding author e.mail. ezarhazaa1000@yahoo.com)-
}

\begin{abstract}
The thyroid hormones, triiodothyronine $\left(\mathrm{T}_{3}\right)$ and its prohormone, thyroxine, are secreted by the thyroid gland which are responsible for the regulation of metabolism in all body tissues. This work aimed to study the histopathological, immunohistochemical and biochemical changes in the adult rat testes after thyroidectomy, in addition to the role of propolis in reducing these changes. Twenty five male Wistar rats were assigned randomly into equal (5) groups; control, sham operated, shamed propolis, thyroidectomized, thyroidectomy treated with propolis. Levels in compare to control the thyroidectomized rats showed significantly decrease in serum $\mathrm{T}_{3}$ and increase in TSH levels. Degeneration and increase in the seminiferous tubules lumen also noticed. Immunohistochemical results showed a remarkable reduction of proliferating cell nuclear antigen (PCNA) and Ki-67 in spermatogonia of thyroidectomized rat testes as compared with control group. The results revealed that, propolis has an ameroliating role on thyroidectomized rats testes by decreasing damage and injury occurred as a result of thyroidectomy.
\end{abstract}

Keywords: Thyroidectomy; Testes; Propolis; PCNA; ki67; Immunohistochemistry.

\section{Introduction}

Thyroid is a butterfly-shaped gland located at the base of the neck. It produces hormones that regulate every aspect of metabolism, from heart rate to calories burn. Removal of all or a part of thyroid gland is called thyroidectomy (Sakr et al., 2015). Thyroidectomy is used to treat thyroid disorders- such as cancer, goiter and overactive thyroid (hyperthyroidism). The growth, development, and metabolic functions of all organs and tissues are affected by thyroid hormones; which have been shown to play an important role in testicular physiology (Holsberger and Cooke, 2005). Gonadotrophin folliclestimulating hormone and luteinizing hormone mainly regulated testicular work (Tousson et al., 2011). MendisHandagama and Siril Ariyaratne (2005) postulated that thyroid hormones have been shown to play a vital role in the onset of Leydig cell differentiation and stimulation of steroidogenesis in postnatal rat testis. Many studies suggested that thyroid hormone required to maintain normal testicular morphology and spermatogenesis in the adulthood and also associated with some kind of sexual malfunction which accompanied by morphological testicular degeneration (Krassas and Pontikides, 2004; Faraone-Mennella et al., 2008). Triiodothyronine (T 3) regulates testicular function and development, Leydig cells, Sertoli cells, and the maturation of germ cells (Wagner et al., 2008). Disturbance in thyroid hormone level is leading to modulate functions of many tissues in mature animals by changing their antioxidant defenses (Das and Chainy, 2004; Chattopadhyay et al., 2007). Total thyroidectomy is a treatment for thyroid cancer, many studies postulated that total thyroidectomy reduces triiodothyronine, thyroxine, prolactin, insulin, and corticosterone levels, and also acid phosphatase activities, while increases cholesterol and glutamic oxaloacetic transaminase activities in rats (Panda and Jindal, 1980, Gomez Dumm., et al 1985).

Bee glue or (Propolis) is a generic name for the resinous substance collected from different plant sources by honeybees (CHEMID, 1996). Monti et al., (1983) and Cirasino et al., (1987) mentioned that propolis composed of $30 \%$ wax, $5 \%$ pollen, $50 \%$ resin and vegetable balsam, $10 \%$ essen- tial and aromatic oils, and 5\% various other substances, including organic debris. Propolis have antiseptic, antimycotic, anti-inflammatory, bacteriostatic, anaesthetic and antioxidant properties (Marcucci, 1995 and Dobrowolski et al., 1991) without side effects or toxicity 
(Jasprica et al., 2007 and Burdock ,1998). Propolis has an immunomodulatory effect restricted to macrophages, without any effects on the proliferation of lymphocyte (Dimov et al., 1991). The present work aimed to investigate the histopathological, immunohistochemical and biochemical changes effects of surgical thyroidectomy performed on the spermatogenesis and structure of the seminiferous tubules in adult rats testes, in addition to the possible ameliorating role of propolais .

\section{Materials and Methods}

\section{i.Experimental animals \& study design}

Twenty five male Wistar rats weighing $130 \pm 5 \mathrm{~g}$ and of 8-9 weeks age were used in this experiment, obtained from Zoology department farm- Tanta- Egypt. Rats were left for one week in the laboratory for accommodation and maintained on a standard rodent diet and water available $a d$ libitum. The rats were divided randomly and equally into five groups as follows: Group (I) control group in which rats did not take any treatment. Group (II) Sham-operated group (control). Group (III) Sham-operated group treated with propolis (50mg/kg body weight) by a stomach tube for 4 weeks, propolis was dissolved in distilled water (Kinobe, et al., 2006). Group (IV) Rats surgically removed thyroid gland (Thyroidectomized) (Tenorio-Velasquez , et al., 2005). Group (V) Thyroidectomized rats treated with propilas (four weeks).

\section{ii.Biochemical and histological study}

After experimental period finished rats were euthanized with sodium pentobarbital, non heparinized blood samples were collected from the inferior vena cava of each rat and centrifugation was done for fifteen minutes at $3000 \mathrm{rpm}$. The concentration of triiodothyronine hormone $\left(\mathrm{T}_{3}\right)$ and thyroid stimulating hormone (TSH) were determined according to Chopra et al. (1971) and Engall et al., (1980) respectively. For histopathological examination, quickly after euthanization, animals were dissected, testes were removed from different groups, and routine method for histopathology was done according to Bancroft and Stevens (1990).

\section{iii. PCNA, P53 and Ki-67 immunoreactivity:}

Expression of PCNA, P53 and Ki-67 were examined in paraffin sections ( $5 \mu \mathrm{m}$ thick) of fixed testes of rats of different groups that mounted on gelatin chromalumcoated glass slides according to the methods described byb Tousson et al. (2011) and Hoeflich et al., (2009) .

\section{iv.Statistical Analysis:}

Data were expressed as mean values \pm SE and statistical analysis were performed using SPSS statistical version 16 software package (SPSS ${ }^{\circledR}$ Inc., USA).

\section{Results}

\section{1.biochemical results}

Thyroidectomized rats showed a significant decreased value of (T3) compared with the control and sham groups
(Table 1). On the other hand, (TSH) levels were significantly increased in thyroidectomized rats comparing with the control and sham groups. Thyroidectomized rats treated with propolis showed significantly decreased (T3) comparing with thyroidectomized rats. On the other hand TSH levels in thyroidectomized and propolis-treated animals were significantly increased compared with thyroidectomized or control groups (Table 1).

Table (1): Changes in $T_{3}(n g / d L)$ and $T S H(\mu I U / m L)$ levels in the different groups

\begin{tabular}{|l|c|c|}
\hline Animal group & $\mathbf{T}_{3}$ & TSH \\
\hline Control (I) & $134.80^{\mathrm{b}} \pm 3.71$ & $0.98^{\mathrm{b}} \pm 0.02$ \\
\hline Sham operated (II) & $133.95^{\mathrm{b}} \pm 3.34$ & $0.87^{\mathrm{b}} \pm 0.05$ \\
\hline $\begin{array}{c}\text { Sham operated \& } \\
\text { Propolis (III) }\end{array}$ & $135.19^{\mathrm{b}} \pm 2.65$ & $0.78^{\mathrm{b}} \pm 0.05$ \\
\hline $\begin{array}{c}\text { Group(IV) : } \\
\text { Thyroidectomized }\end{array}$ & $71.26^{\mathrm{a}} \pm 2.54$ & $2.59^{\mathrm{a}} \pm 0.18$ \\
\hline $\begin{array}{c}\text { Group(V) : } \\
\text { Thyroidectomized \& } \\
\text { Propolis }\end{array}$ & $92.55^{\mathrm{a}} \pm 2.71$ & $1.23^{\mathrm{ab}} \pm 0.11$ \\
\hline
\end{tabular}

a,b: means in the same column with different superscript are significantly different $(\mathrm{P} \leq 0.05)$.

\subsection{Histological observations:}

The seminiferous tubules and interstitial tissues are the main structural components of the control testis. Figures (1A-1C) showed stages of spermatogenesis in testes sections of control, sham-operated and shamoperated treated with propolis groups. Two types of cells are identified in rat seminiferous tubules, the Sertoli cells and the spermatogenic cells (spermatogonia, primary spermatocytes, secondary spermatocytes, spermatids and sperms). The Sertoli cells, rest on the thin basal lamina (basement membrane) while the spermatogenic cells are arranged in many layers, namely the spermatogonia, primary and secondary spermatocytes; spermatoids and finally mature spermatozoa. However, many abnormalities were revealed in testis sections of the thyrodectomized rat as inhibition of spermatogensis, little numbers of Leydig cells, marked atrophy and degeneration with a significant decrease in the number of spermatogenic cells in the seminiferous tubules, degenerative Sertoli cell and an increase in the seminiferous tubules lumen with lack of sperms when compared with control group (Figs. 1D\&1E). Sections in testes of thyroidectomized rats that treated with propolis for 4 weeks revealed moderate improvement with regular distribution in spermatogenesis cycles, mild degeneration and atrophy with a significant increase in the number of spermatogenic cells in the seminiferous tubules, an increase in the sperm and Leydig cells numbers when compared with thyroidectomized rats (Fig. 1F). 



Figure 1: Photomicrographs of rat testes stained with hematoxylin and eosin (HE). Figs. (1A-1C) showed regular cycle of spermatogenesis in testes sections of control, sham-operated and sham-operated treated with propolis groups. The thyroidectomized rat, with a significant decrease in the number of spermatogenic cells in the seminiferous(black arrow) tubules, degenerative sertoli cell(white arrow) and an increase in the seminiferous tubules lumen with lack of sperms (Figs. 1D\&1E). Tyroidectomized rats that treated with propolis with regular distribution in spermatogenesis cycles, mild degeneration and atrophy with a significant increase in the number of spermatogenic cells in the seminiferous tubules (Fig. 1F).

\section{3 immunohistochemical result:}

\section{PCNA immuohistochemical alterations in testes:}

The detection and distribution of PCNA immunoreactivity (PCNA-ir) in the testes sections in the different groups were revealed in figure 2. Testes sections in control, sham-operated and sham-operated treated with propolis groups showed strong positive reaction for PCNA in the spermatogonia (Figs. 2A-2D). Testes sections in thyrodectomized rat revealed a marked decrease of PCNAir in many spermatogonia as compared to control group rats (Figs. 2E). However, moderate numbers of spermatogonia that have positive reaction for PCNA-ir were detected in the testes of thyroidectomized rats that treated with propolis (Fig. 2F).

Figure 2: Photomicrographs of (PCNA-ir) in the testis sections of control rats(A,B), shamed(C) and shamed treated with propolis (D), spermatogonia cells in the seminiferous tubules (arrows) showing the distribution of PCNA-ir positive cells. (E), negative reaction of PCNA-ir in spermatogonia (arrows). (F), moderate reaction for PCNA-ir in spermatogonia (arrows). PCNA indicates proliferating cell nuclear antigen.

\section{Ki-67 immunoreactivity:}

Figure (3) showed the detection and distribution of Ki-67 immunoreactivity, testes sections in control (G1), sham-operated (G2) and sham-operated treated with propolis (G3) groups. A positive reaction for Ki-67was observed only in the spermatogonia (Figs. 3A-3D). Marked decrease in Ki-67 immunoreactivity was detected in thyrodectomized rat testis sections compared to control group (Figs.3E). On the other hand the testes of thyroidectomized rats that treated with propolis showed moderate numbers of spermatogonia that have positive reaction for Ki-67 immunoreactivity (Fig. 3F).

\section{P53 immunoreactivity:}

Figure (4) showed the detection and distribution of P53 immunoreactivity, in rat testes of control rats(A), shamed(B) and shamed treated with propolis (C). Spermatogonia cells in the seminiferous tubules showing low reaction for the distribution of P53-ir, while in the thyroidectomized group a positive reaction was noticed (D,E), P53 showing low reaction in thyroidectomized group treated with propolis $(\mathrm{F})$. 

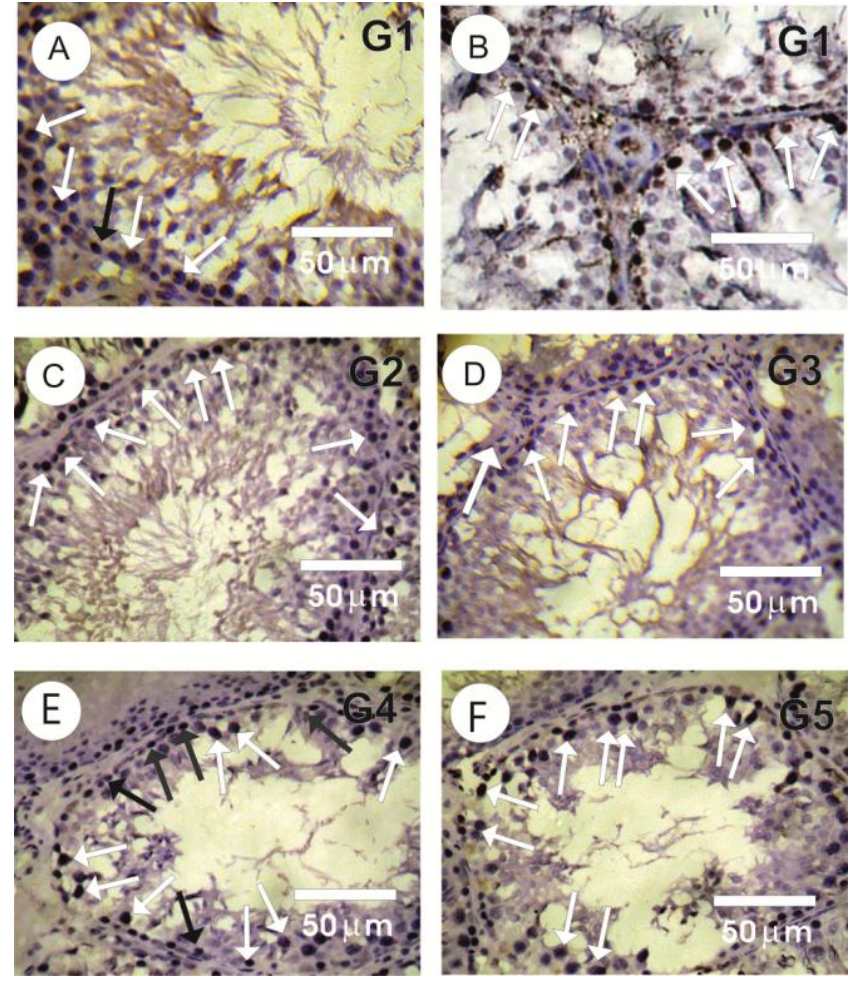

Fig (3): showed the detection and distribution of Ki-67 immunoreactivity, testes sections in control (G1), shamoperated (G2) and sham-operated treated with propolis (G3) groups showed positive reaction for Ki-67 only in the spermatogonia (Figs. 3A-3D). Marked decrease in Ki-67 immunoreactivity was detected in thyrodectomized rat testis sections compared to control group rats (Figs.3E). On the other hand the testes of thyroidectomized rats that treated with propolis showed moderate numbers of spermatogonia that have positive reaction for $\mathrm{Ki}-67$ immunoreactivity (Fig. 3F).

\section{Discussion}

Hypothyroidism that produced by thyroidectomy or goitrogen treatment has many side effects on testicular function and reduction of gonadotrophins (Gomes, 1970 and Bruni et al.,1975). Thyroid hormones regulate many body activities including growth, development, oxygen consumption, respiration, digestion strength, carbohydrate, lipid and protein metabolism, central nervous system function, and the actions of other endocrine glands (Toshihiro 2010, Massoud et al., 2012, Salama et al., 2013).

The present study investigated the protetive effect of propolis against testicular toxicity induced by thyroidectomy in male rats. Thyroidectomized rats showed depression of $T_{3}$ levels while TSH levels was increased in indicating that hypothyroidism have been done.. This result is in agreement with Tousson et al., $(2012,2014)$ and Ali et al., (2013) that used thyroidectomy to achieve hypothyroid state. Choksi et al., (2003) mentioned that the elevation of TSH level can be explained by the less production of $\mathrm{T}_{3}$ from thyroid gland and that minimizes TSH feedback inhibition leading to an elevation of its value. Also it has been reported that serum FSH levels were reduced after chronic T3 administration (Aruldhas et al., 1982;Majdic et al., 1998).

Histopathological results showed that testes of thyroidectomy rats revealed a variety of histopathological lesions when compared with control or sham operating groups. Marked histological changes were detected in the testes of mature rats under prolonged deficiency of thyroid hormones (Wagner et al., 2009). Testes in thyroidectomized rats showed many of changes as incomplete of spermatogensis, little numbers of Leydig cells, marked degeneration and significant decrease in the number of spermatogenic cells and an increased in the seminiferous tubules lumen with lack of sperms when compared with control group. These results are in agreement with a number of studies which provided evidence that hypothyroidism causes an adverse effect on the reproduction (Tousson et al., 2011, 2012). Prolonged hypothyroidism induced in rats by chemicals leads to arrest proliferation and differentiation of germ cells, leading to decreased germ cells number and the percentage of live sperm (Sahoo et al., 2007).

Previous reports indicated that both PCNA and Ki67 used as a marker of cell proliferation in ameloblastomas (Meer et al., 2003). Immunohistochemical observations of the testes sections showed a marked decrease of the PCNA immunoreactivity after thyrodectomy. Strong reaction for PCNA was detected in the control and sham testes sections. Ki-76 immunoreactivity showed a little to moderate number of spermatogonia that have positive reaction in testes treated with propolis. These results are in agreement with Tousson et al. (2011) who reported that; proliferating cell nuclear antigen depress in spermatogonia of hypothyroid rats. The decrease in PCNA positive expression may be due to DNA damage in the abscence cell cycling (De olivera et al., 2008: Mighell 1995). Molina et al., (2013) reported that in his study higher percentage of PCNA compared to Ki-67 and these results are in agreement of this work as PCNA is more positive than Ki67 in control, shamed and shamed with propolis. P53 was significantly increased in thyroidectomized rats, while decreased to be like normal in thyroidectomized rats treated with propolis. p53-dependent apoptosis appears responsible for the initial phase of germ cell loss in experimental cryptorchidism based on a 3-day delay of apoptosis in p53-/- mice (Yin et al.2002).. Wang et al., (2005) reported that apoptosis is a protective mechanism to the body by destruction of genetically damaged cells. Many reports mentioned that thyroid hormones have antiapoptotic activity, Mukherjee et al., (2014) postulated that administration of T3 rescue hypothyroid liver cells from apoptosis done by oxidative stress. Thyroid hormone plays an important role in expression of MCLI, by which mitochondrial membrane destabilization was prevented ,leading to stop cytochrome c channels by which apoptotic induced Pietrzak and Puzianowska (2008). 
The obtained results showed that treating thyroidectomized rats with propolis improved the testicular histopathological as well as immunohistochemical alterations. Moreover, T3 and TSH returned to its normal values. These results are in accordance with previous investigators who studied the ameliorative effects of propolis against testicular damage. El Mazoudy et al. (2011) postulated that administration of propolis increased seminal vesicles and prostate weights and reduced the damage effects of cyclosporine-A. Capucho et al. (2012) and Rizk et al. (2014) mentioned that propolis can increase the number of sperms in rats testis. Propolis protects the male reproductive system from testicular dysfunction, deterioration in semen quality and testosterone levels (Yousef and Salama, 2009; Ogretmen et al., 2014). Many investigators postulated that the amerolating effect of propolis against reproductive toxicity was attributed to its antioxidant activity Yousef and Salama, 2009. Therefore, the present study elucidated the therapeutic effects of propolis administered to minimize the effects of thyroidectomized on reproductive toxicity.
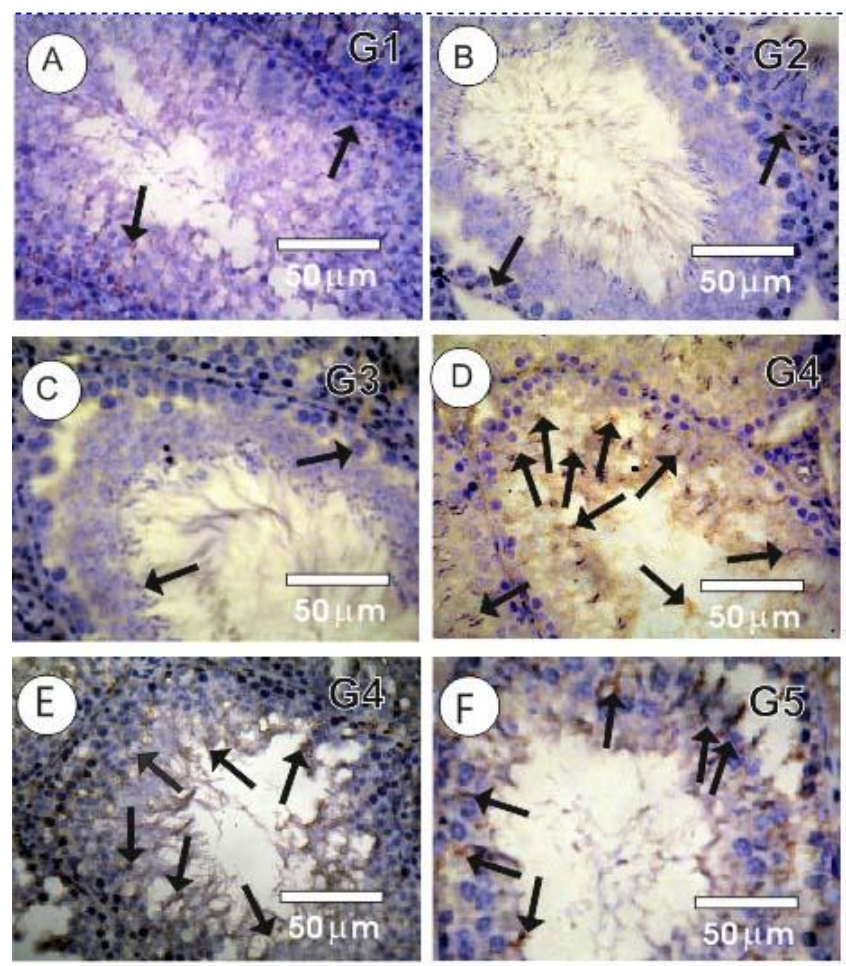

Fig(4): showed the detection and distribution of P53 immunoreactivity, in rat testes of control rats(A), shamed(B) and shamed treated with propolis (C), spermatogonia cells in the seminiferous tubules showing low reaction for the distribution of P53-ir, while in the thyroidectomized group a positive reaction was noticed $(\mathrm{D}, \mathrm{E})$ apoptotic marker showing low reaction in thyroidectomized group treated with propolis (F).

\section{References}

Ali, E., Ibrahim, W., Ashraf, R.M., Tousson E. 20131. Interrelationship of heme oxygenase and the oxidative stress in the cardiac tissues of thyroidectomized rats. Pharmacologia 4(12)2): 623-633.

Aruldhas, M.M., Valivullah, H.M., Govindarajulu, P. (1982). Specific effect of thyroid hormone testicular enzymes involved in carbohydrate metabolism. Biochem. Biophys. Acta 715: 121-125.

Bancroft, J.D., Stevens, A. (1990). Theory and Practice of Histological Technique. $3^{\text {rd }}$ Ed. Churchill Livingstone. Edinburgh, London.

Bruni, J.F.,S. Marshall, J.A. Dibbet and J. Meites. (1975). Effect of hyper- and hypothyroidism on serum LH and FSH levels in intact and gonadectomised male and female rats. Endocrinology 97:558-563.

Burdock, G.A. (1998). Review of the biological properties and toxicity of bee propolis (propolis). Food and Chemical Toxicology 36: 347-363.

Capucho, C., Sette, R., Predes, F., Monteiro, J.C., Pigoso, A.A., Barbieri, R., Heidi, Dolder, M.A., Severi Aguiar, G.D.C. (2012). Green Brazilian propolis effects on sperm count and epididymis morphology and oxidative stress. Food Chem Toxicol, 50:3956-3962.

Chattopadhyay, S., Sahoo, D.K., Subudhi, U., Chainy, G.B.N. (2007). Differential expression profiles of enzymes and glutathione redox status in hyperthyroid rats: a temporal analysis. Comp. Biochem. Physiol. C146: 383391.

Chemid, (1996). A chemical database sponsored by the National Library of Medicine. Bethesda, MD.

Choksi, N.Y., Jahnke, G.D., Hilaire, C.S., Shelby, M. (2003). Role of thyroid hormones in human and laboratory animal reproductive health. Birth Defects Res. B. 68: 479-491.

Chopra, I.J., Solomon, D.H., Ho RS. (1971). A radioimmunoassay of triiodothyronine. J. Clin. Endocrinol. 833: 65

Cirasino, L., Pisati, A., and Fasani, F. (1987). Contact der- matitis from propolis. Contact Dermatitis 16, 110-111.

Cooke, P.S, Holsberger, D.R., Witorsch, R.J., Sylvester, P.W., Meredith, J.M., Treinen, K.A., Chapin, R.E. (2004). Thyroid hormone, glucocorticoids, and prolactin at the nexus of physiology, reproduction, and toxicol- ogy. Toxicol Appl Pharmacol 194:309-335.

Das, K., Chainy, G.B.N. (2004). Thyroid hormone influences antioxidant defence in adult rat brain. Neurochem. Res. 29: 1755-1766.

De Oliveira, M.G., Lauxen Ida, S., Chaves, A.C., Rados, P.V., Sant'AnaFilho, M. (2008) Immunohistochemical analysis of the patterns of p53 and PCNA expression in odontogenic cystic lesions. Med Oral Patol Oral Cir Bucal 13:E275-80.

Dimov, V., Ivanovska, N., Manolova, N., Bankova, V., Nikolov, N., Popov, S. (1991). Immunomodulatory action of propolis. Influence on anti-infections protection and macrophage function. Apidologie 22: 155-162. 
Dobrowolski, J. W., Vohora, S. B., Sharma, K., Shah, S. A., Naqvi, S. A. H., and Dandiya. P. C. (1991) Antibacterial, antifungal, antiamoebic, antiinflammatory and antipyretic studies on propolis bee products. Journal of Ethnopharmacology 35: 77-82.

Engall, E.,Van Vunakis, H., Langone, J.J. (1980). Methods in Enzymology Academic Press, New York. 70: 419-492.

ElMazoudy, R.H, Attia, A.A., El-Shenawy, N.S. (2011). Protective role of propolis against reproductive toxicity of chlorpyrifos in male rats. Pestic Biochem Physiol 101:175-181.

Faraone-Mennella, M.R., Ferone, A., Marino, L., Cardone, A., Comitato, R., Venditti, P., Di Meo, S., Farina, B. (2008). Poly(ADP-ribosyl)ation of pro- teins and germ cell development in hyperthyroid rat testes. Mol Cell Biochem 323:119-129.

Gomes, W.R. (1970). Metabolic and Regulatory hormones influencing Testes function in the Testes. A.D. Johnson, W.R. Gomes and N.L. Vandemark, Eds., Academic Press, New York. Vol. 11, pp. 68-114.

Gomez Dumm, C.L., Cortizo, A.M., Gagliardino, J.J. (1985.) Morphological and functional changes in several endocrine glands induced by hypothyroidism in the rat. Acta Anat (Basel) 124: 81-87.

Holsberger, D.R., Cooke, P.S. (2005). Understanding the role of thyroid hormone in Sertoli cell development: A mechanistic hypothesis. Cell Tissue Res 322:133-140.

Hoeflich, K. P., Herter, S., Tien, J., Wong, L., Berry, L., Chan, J., O'Brien, C., Modrusan, Z., Seshagiri, S., Lackner, M., Stern, H., Choo, E., Murray, L., Friedman, L. and Belvin, M. (2009): Antitumor efficacy of the novel RAF inhibitor GDC-0879 is predicted by BRAFV600E mutational status and sustained extracellular signalregulated kinase/mitogen-activated protein kinase pathway suppression. Cancer research, AACR, 69: 30423051.

Ibrahim, W., Abo Gazia, M., El-Atrash, A., Massoud, A., Tousson, E., and Abou-Harga, H. (2012). Ameliorative effect of folic acid on propylthiouracilinduced histological and immunohistochemical alterations in aorta of albino rats. Journal of American Science 28(3) 262-270.

Ibrahim, W., Tousson, E., Ali, E.M., Mansour, M.A. (2011). Folic acid alleviates oxidative stress and hyperhomocysteinemia involved in testicular dysfunction of hypothyroid rats. General and Comparative Endocrinology 174: 143-149.

Ibrahim, W., Tousson, E., El-Masery, T., Arafa, N., Akela, M. (2012). The effect of folic acid as an antioxidant on the hypothalamic monoamines in experimentally induced hypothyroid rat. Toxicology and Industrial Health 28(3):253-61.

Jasprica, I., Mornar, A., Debeljak, Z., SmolcicBubalo, A., Medic-Saric, M., Mayer, L., Romic, Z., Bucan, K., Balog, T., Sobocanec, S., Sverko, V. (2007). In vivo study of propolis supplementation effects on antioxidative status and red blood cells. Journal of Ethnopharmacology 110, 548-554.

Krassas, G.E., Pontikides, N. (2004). Male reproductive function in rela- tion with thyroid alterations. Best Pract Res Clin Endocrinol Metab 18:183-195.

Kinobe, R.T., Dercho, R.A., Vlahakis, J.Z., Brien, J.F., Szarek, W.A., and Nakatsu, K. (2006). Inhibition of the Enzymatic Activity of Heme Oxygenases by AzoleBased Antifungal Drugs. J Pharmacol Exp Ther.319(1):277-84.

Marcucci, M. C. (1995). Propolis: Chemical composition, biological properties and therapeutic activity. Apidologie 26, 83-99.

Macleod, K.F., Hu Y and Jacks, T. (1996). Loss of $\mathrm{Rb}$ activatesboth P53-dependent and independent cell death pathways in the developing mouse nervous system. EMBO J 15: 6178-6188.

Massoud, A., El-Atrash, A., Tousson, E., Ibrahim, W., Abou-Harga, H. (2012). Light and ultrastructural study in the propylthiouracil-induced hypothyroid rat heart ventricles and the ameliorating role of folic acid. Toxicology and Industrial Health 28(3): 262-270.

Majdic, G., Sno, J., Horvat, A., Mrkun, J., Kosec, M., Cestnik, V. (1998). Higher thyroid hormone levels in neonatal life result in reduced testis volume in postpubertal bulls. Int. J. Androl 21: 352-357.

Meer, S, Galpin, J.S., Altini, M., Coleman, H., Ali, H. (2003). Proliferating cell nuclear antigen and Ki67 immunoreactivity in ameloblastomas. Oral Surg Oral Med Oral Pathol Oral Radiol Endod 95:213-21.

Mendis-Handagama, S.M., Siril Ariyaratne, H.B. (2005). Leydig cells, thy- roid hormones and steroidogenesis. Indian J Exp Biol 43:939-962.

Mighell, A. (1995). PCNA and p53. Eur J Cancer B Oral Oncol 31B:403-4.

Mukherjee, S., Samanta, L., Roy, A., Bhanja, S., Chainy G.B. 2014.Supplementation of T3 recovers hypothyroid rat liver cells from oxidatively damaged inner mitochondrial membrane leading to apoptosis. BioMed Res Int. :590897.

Li, T.J., Browne, R.M., Matthews, J.B. (1995). Expression of proliferating cell nuclear antigen (PCNA) and Ki-67 in unicystic ameloblastoma. Histopathology 26:219-28.

Molina, R. B. et. al. (2013): Comparison of the value of PCNA and Ki-67 as markers of cell proliferation in ameloblastic tumors. Med Oral Patol Oral Cir Bucal. 18 (2):e174-9.

Monti, M., Berti, E., Carminati, G., and Cusini, M. (1983) Occupational and cosmetic dermatitis from propolis. Contact Dermatitis 9, 163.

Panda, J.N, Jindal, S.K. (1980). Effect of thyroidectomy and adrenalectomy on the physiochemical status of rat testes. Andrologia 12:444-447

Park, D.S., Levine, B., Ferrari, G., and Greene, L.A. (1997) Cyclin dependent kinase inhibitors and dominant negative cyclin dependent kinase 4 and 6 promote survival of NGF-deprived sympathetic neurons. Journal of Neuroscience 17: 8975-8983. 
Pietrzak, M., Puzianowska-Kuznicka, M. (2008). Triiodothyronine utilizes phosphatidylinositol 3-kinase pathway to activate anti-apoptotic myeloid cell leukemia-1. J Molec Endocrinol.; 41:177-186.

Ogretmen, F., Inanan, B.E., Ozturk, M. (2014). Protective effects of propolis on cryopreservation of common carp (Cyprinus carpio) sperm. Cryobiology 68:107-112.

Rizk, S.M., Zaki, H.F., Mina, M.A.M. (2014). Propolis attenuates doxorubicin-1nduced testicular toxicity in rats. Food Chem Toxicol 67:176-186.

Sahoo, D.K., Roy, A., Bhanja, S., Chainy, G.B. (2007). Hypothyroidism impairs antioxidant defence system and testicular physiology during development and maturation. Gen Comp Endocrinol 156:63-70.

Sakr, S. A., et. al. (2015). Effect of folic acid on Lthyroxin induced nephrotoxicity in alino rats. ejpmr, 2(7), 43-51.

Salama, A.F., Tousson, E., Ibrahim, W., Hussein, M.W. (2013). Biochemical and histopathological studies in the PTU-induced hypothyroid rat kidney with reference to the ameliorating role of folic acid. Toxicology and Industrial Health 29(7):600-608.

Snedecor, J.O., K.L. Raheja and R.A. Freedland. (1972). Effect of single injection of Thyroxine on glycolytic and other enzymes in the propylthiouracil fed cockerels. Gen. comp. Endocr 18,199-209.

Tenorio-Velasquez, V.M., Barrera, D., Franco, M., Tapia E., Hernandez-Pando, R., Medina-Campos, O.N., et.al. (2005). Hypothyroidism attenuates protein tyrosine nitration, oxidative stress and renal damage induced by ischemia and reperfusion: effect unrelated to antioxidant enzymes activities. BMC Nephrol 7: 6-12.
Toshihiro, I. (2010). Thyroid hormone and atherosclerosis. Vascul Pharmacol 52:151-156.

Tousson, E., Ali, EM., Ibrahim, W., Mansour, M.A. (2011). PCNA as a Molecular Biomarker for Spermatogenesis in PTU- Induced Hypothyroidism of Rats. Reproductive Sciences 18: 679-686.

Tousson, E., Ali, E. M., Ibrahim, W., Ashraf RM.( 2012). Histopathological and immunohistochemical alterations in rat heart after thyroidectomy and the role of hemin and ketoconazole in treatment. Biomedicine ., Pharmacotherapy 66: 627-632.

Yin Y, Stahl BC, DeWolf WC, Morgentaler A.(2002). P53 and Fas are sequential mechanisms of testicular germ cell apoptosis. J, Androl ,23(1):64-70.

Yousef, M.I., Salama, A.F. (2009). Propolis protection from reproductive toxicity caused by aluminium chloride in male rats. Food Chem Toxicol, 47,1168-1175.

Venditti, P., Balestrieri, M., Di Meo, S., De Leo, T. (1997). Effect of thyroid state on lipid peroxidation, antioxidant defences and susceptibility to oxidative stress in rat tissues. J. Endocrinol 155, 151-157.

Wang, L, Bowman, L., Lu, Y., Rojanasakul, Y., Mercer RR, Castranova V, et al. (2005). Essential role of P53 in silica-induced apoptosis. American Journal of Physiology288: 488-496.

Wagner, M.S. Wajner, S.M. and Maia, A.L. (2008): The role of thyroid hormone in testicular development and function. J. Endocrinol 199 , 351-365.

Wagner, M.S. Wajner, S.M. and Maia, A.L. (2009): Is There a Role for Thyroid Hormone on Spermatogenesis? Microscopy research and technique 72:796-808 . 